\title{
Erratum to SPIO-loaded nanostructured lipid carriers as liver- targeted molecular T2-weighted MRI contrast agent
}

\section{Editorial Office}

Quantitative Imaging in Medicine and Surgery

Correspondence to: Editorial Office. Quantitative Imaging in Medicine and Surgery. Email: qims@amepc.org.

Submitted Oct 15, 2021. Accepted for publication Oct 25, 2021.

doi: 10.21037/qims-2021-05

View this article at: https://dx.doi.org/10.21037/qims-2021-05

Erratum to Quant Imaging Med Surg 2018;8:770-80

The article "SPIO-loaded nanostructured lipid carriers as liver-targeted molecular T2-weighted MRI contrast agent" (Quant Imaging Med Surg 2018;8:770-80), written by Zhu et al. (1), was published with an error.

This article (1), that appeared on page 776, unfortunately contained a mistake in Figure 4. In vitro cellular uptake of MNLC in different cell lines in Figure 4 (Fluorescence images observed by confocal microscopy and fluorescence intensity inside cells measured by flow cytometry of LO2 cells incubated with NLC-SPIO and Gal-NLC-SPIO/PEG for 12 h, respectively) were duplicate. The correct images of Figure 4 are presented in this erratum. This correction does not change the conclusions of the article.

The corrected version of Figure 4 is presented here (Figure 4). 
The authors regret the errors.

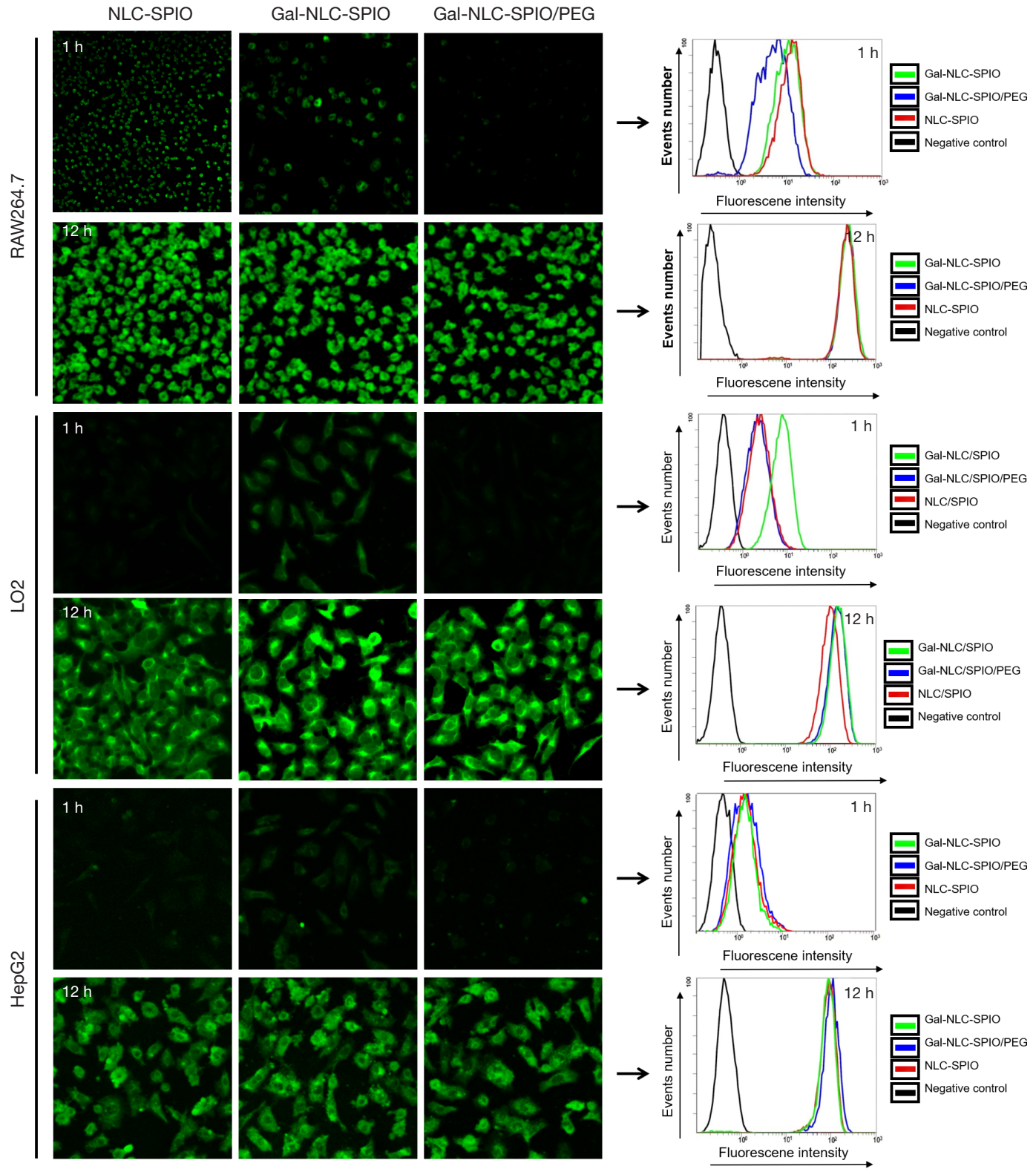

Click here to view the updated version of the article.

Open Access Statement: This is an Open Access article distributed in accordance with the Creative Commons AttributionNonCommercial-NoDerivs 4.0 International License (CC BY-NC-ND 4.0), which permits the non-commercial replication and distribution of the article with the strict proviso that no changes or edits are made and the original work is properly cited (including links to both the formal publication through the relevant DOI and the license). See: https://creativecommons.org/licenses/by-nc$\mathrm{nd} / 4.0 /$. 


\section{References}

1. Zhu X, Deng X, Lu C, Chen Y, Jie L, Zhang Q, Li W, Wang Z, Du Y, Yu R. SPIO-loaded nanostructured lipid carriers as livertargeted molecular T2-weighted MRI contrast agent. Quant Imaging Med Surg 2018;8:770-80.

Cite this article as: Editorial Office. Erratum to SPIO-loaded nanostructured lipid carriers as liver-targeted molecular T2weighted MRI contrast agent. Quant Imaging Med Surg 2022;12(2):1660-1662. doi: 10.21037/qims-2021-05 